371.3::811.163.41'36

811.163.41'366

https://doi.org/10.18485/kij.2018.65.3_4.9

ЉИЉАНА Ј. КЕЛЕМЕН МИЛОЈЕВИЋ *

Висока школа струковних студија за васпитаче

„Михаило Палов”, Вршац

ЗОРИЦА В. ЦВЕТАНОВИЋ

Универзитет у Београду, Учитељски факултет

Београд
Оригинални научни рад

Примљен: 05. 11. 2018.

Прихваћен: 15. 11. 2018.

\title{
МИШЉЕЊА УЧИТЕЉА О УСВОЈЕНОСТИ ГРАМАТИЧКИХ КАТЕГОРИЈА У РАЗРЕДНОЈ НАСТАВИ СРПСКОГ ЈЕЗИКА
}

\begin{abstract}
Усвајање морфолошких појмова, посебно одређених граматичких категорија у млађим разредима основне школе, програмски је задатак у разредној настави. Циљ рада је представљање граматичких категорија речи које се дефинишу и усвајају у разредној настави, приказ обављеног истраживања о усвајању тих појмова и могућа решења за превазилажење уочених проблема у настави граматике. У овом раду доносимо резултате истраживања спроведеног са циљем да се испитају мишљења учитеља о проблемима при усвајању граматичких категорија у настави граматике на млађем узрасту ученика. Анонимни анкетни упитник попунило је 106 учитеља у једанаест основних школа на територији Републике Србије. Резултати истраживања показали су да ученицима, према мишљењу учитеља, највеће проблеме представљају мање познате речи српскога језика и изузеци у промени именских речи, те да већина ученика млађег узраста јасно не разликује граматичко-морфолошке појмове, неправилно пише одричну речцу не са глаголима у личном облику и неправилно изговара и пише неке облике придева и прилога у компаративу и суперлативу. То нам говори да су потребни интензивнији, методички моделовани часови утврђивања и обнављања градива, односно повезивање часова граматике са наставом књижевности, културе изражавања и правописа.
\end{abstract}

Кључне речи: граматичке категорије, морфологија, променљиве врсте речи, настава граматике, настава српског језика.

\section{Увод}

Настава граматике све више укључује комуникативну функцију и постаје средство у остваривању култивисања језичке комуникације. Она у млађим разредима основне школе у највећој мери обухвата усвајање основних појмова из

*ljiljana.kelemen@uskolavrsac.in.rs 
морфологије и синтаксе. Још се од Старе Грчке у образовању изучавала граматика као основа за говорење и писање, а интересовање за ову научну област увек је било присутно, и са теоријске стране и практично, у учењу и примени.

У савременој настави граматике у центру пажње је функција и значење језичких појава, а форме њиховог испољавања посматрају се као разноврсност њихових функционалних и значењских могућности. Језичке појаве се уче осмишљено, док се појмови и законитости усвајају свесно и постају део ученичких изражајних потенцијала. Другим речима, ученик се ставља у повољнији положај, јер се подстиче да проучавањем и анализом текста открива граматичке појаве у контексту.

Усвајање морфолошких појмова, посебно граматичких категорија у млађим разредима основне школе, прате многи проблеми које треба превазићи савременим методичким приступима који, између осталог, подразумевају садржаје, методе, принципе и облике рада прилагођене ученицима млађег узраста. „Одређене потешкоће оптерећују изучавање граматике у школи, али те потешкоће могу се веома успешно превазићи коришћењем веома ефикасних и функционалних методичких поступака и облика рада" (Милатовић 2011: 384). Стога смо у раду најпре сагледали усвајање научних и ненаучних разноврсних појмова у контексту теорија учења и наставе, а потом смо дали приказ елементарних појмова из морфологије које ученици треба да усвоје у првом циклусу основношколског образовања и укратко објаснили појам граматичких категорија. У посебном сегменту овога рада представљени су резултати експлоративног истраживања који се односе на мишљења учитеља о проблемима који се јављају при усвајању граматичких категорија у настави граматике (морфологије), као и методичке смернице за решење изнетих проблема.

\section{Усвајање научних и ненаучних појмова у контексту теорија учења и наставе језика}

Настава граматике у првом циклусу обавезног образовања представља први корак ка усвајању појмова из морфологије, који се даље продубљују у старијим разредима основног образовања и у средњем образовању. Методички приступ садржајима из морфологије треба да се заснива на истовременом разумевању и уважавању обележја и односа морфолошких појмова (врсте речи, род, број, падеж, лице итд.) у систему психолошких процеса усвајања тих појмова на одговарајућем узрасту. Проблемима усвајања појмова бавили су се психолози и лингвисти. Према Ж. Пијажеу (J. Piaget) и Б. Инхелдеру (B. Inhelder) (Пијаже, Инхелдер 1982), у процесу учења значајно је продуктивно учење, разумевање ученог и креативност ученика који сам експериментише, посматра, проверава, решава проблеме и открива. За разлику од усвајања оваквих, спонтаних појмова, Л. Виготски (1996: 144-221) уводи термин „научни појам”, а под њим подразумева појмове који се стичу систематичним наставним радом у школском добу. 
Слично Пијажеовом схватању, да процес развоја појмова пролази кроз различите фазе, по америчком психологу Д. Оусубелу (D. Ausubel) нивои развоја појмова cy: „преоперационални, конкретно-операционални и апстрактно-логички ниво” (Оусубел 1962: 213-244). Он назива своју когнитивну теорију смисаоним вербалним учењем и посебно је истакао како ученици у млађим разредима основне школе уче појмове самосталним открићем, тј. индуктивним путем. Основне категорије у тој теорији су: „смисао, учење и когнитивна структура” (Вилотијевић 2000: 279). За разлику од Пијажеа, овај аутор више инсистира на процесима учења, него на исходима или резултатима, те је у том смислу сличног мишљења као и Виготски.

Усвајањем појмова у настави бавио се и српски лингвиста Ж. Цветковић (1982), који наглашава да је „разматрање природе и развоја одређеног појма могуће само ако га посматрамо у повезаности са осталим појмовима са којима сачињава систем” (Цветковић 1982: 28). Он сматра да се савременој настави постављају високи захтеви у погледу квалитета усвојености појмова, јер се од ученика тражи да усвоје појмове са разумевањем, како би их функционално користили у даљем учењу и раду. Постоје препоруке да од самог почетка школовања деца треба да усвајају знања развијањем правих појмова (Лазаревић 1999: 162). Зато је потребно, примерено узрасту деце, уводити појмове упознавањем с дефиницијама тих појмова, али тако да деца овладају структуром дефиниције. Дакле, за развој научних појмова и појмовног мишљења потребно је конципирати наставу која има атрибуте активне наставе, која се базира на кооперацији између учитеља и ученика, као и ученика међусобно.

Усвајање граматичких појмова је један од најсложенијих процеса у наставном раду, те је на млађем школском узрасту веома битно да се у том процесу користе разноврсни извори знања, да се учитеља придржавају принципа очигледности и да што чешће комбинују конкретно са апстрактним. Јасност и трајност усвојених појмова зависе, пре свега, од тога како су формирани, у којој су мери ученици били активни у наставном процесу и самостално закључивали, а у којој су знања исказана без непосредног учешћа ученика, што се сматра врло штетним по ученике и њихов даљи интелектуални развој.

\section{Елементарни појмови из морфологије у програмима за млађе разреде основне школе}

Ученици млађих разреда основне школе многе појмове из граматике усвајају интуитивним путем. Интуитивни пут је облик сазнавања на непосредан начин. До сазнања се долази без мисаоних операција, односно без помоћи логичког закључивања. Наставни програми, које прописује Министарство просвете Републике Србије, предвиђају поступно и систематично упознавање садржаја из морфологије, упознавање језичких појава и појмова, овладавање нормативном граматиком и стилским могућностима језика. Ови програми предвиђају да се у 
настави језика ученици оспособе за правилну усмену и писмену комуникацију стандардним српским језиком. Отуда захтеви у програму нису усмерени само на језичка правила и граматичке норме већ и на њихову функцију.

Елементарни појмови из морфологије српског језика почињу се уводити у наставу од другог разреда основне школе и поступно се проширују и продубљују из разреда у разред. Према Правилнику о наставном плану и програму за први и други разред основног образовања и васпитања (2004: 2-10), у првом разреду се из поменуте области уводи само појам речи. Ученици постепено уочавају основне граматичке категорије, и то најпре речи које мењају своје облике и значења у зависности од службе речи у реченици, а тек у четвртом разреду основне школе ученицима се уводи појам непроменљивих врста речи без именовања посебних врста тих речи. У другом разреду се уводе појмови именица и глагола на нивоу уочавања и препознавања (имена бића и предмета и разликовање рода и броја именица; речи које означавају само радњу и разликовање основних глаголских облика за исказивање садашњег, прошлог и будућег времена; разликовање потврдних и одричних глаголских облика).

Према Правилнику о Наставном програму за трећи разред основног образовања и васпитања (2005: 2-9), у овом разреду се уводе појмови заједничких и властитих именица, речи које именују појаве и проширује се знање о роду као класификационој категорији и броју именица као морфолошкој категорији; уводе се речи које означавају, осим радње, стање и збивање, као и разликовање лица и броја глагола, а проширују се и знања о потврдним и одричним облицима глагола и о разликовању глаголског облика којима се означава садашњост, прошлост и будућност. По први пут се уводи појам придева, и посебне врсте - описних и присвојних и њихов род и број. У четвртом разреду се, према важећем Правилнику о наставном програму за четврти разред основног образовања и васпитања (2006: 4-11), обнавља и утврђује знање усвојено у претходним разредима и јасно се истичу и уочавају речи које у говору и писању мењају свој основни облик (променљиве речи), без дефиниција и захтева за променом по падежима и временима. Затим се уочавају речи које задржавају свој основни облик у свим ситуацијама (непроменљиве речи), без именовања врста тих речи. По први пут се уводе и појмови збирних и градивних именица, њихов род и број. Затим се уводе појмови градивних придева, личних заменица, род и број личних заменица и главних (основних) и редних бројева. У четвртом разреду основне школе уводе се и појмови и основна значења презента, перфекта и футура.

Дакле, у првом и другом разреду основног васпитања и образовања, у оквиру вежби слушања, говорења, читања и писања ученици запажају језичке јединице најчешће без њиховог дефинисања, да би се од трећег до осмог разреда у концентричним круговима и континуираним низовима граматички садржаји изучавали поступно и селективно у складу са узрастом ученика. При реализацији првог циклуса изучавања морфологије (од 1. до 4. разреда основне школе) важно је обрађивати темељно управо оне елементе појмова на које ће се надовезивати садржаји у старијим разредима. 


\section{Морфолошке и класификационе вредности граматичких категорија и настава граматике у млађим разредима основне школе}

Појам граматичких категорија је комплексан. У Нормативној граматищи српскога језика, граматичке категорије са нормативистичког становишта се дефинишу „као јединство граматичког облика и граматичког значења, а испољавају се, пре свега, у граматици речи (морфологија) и граматици реченице (синтакса), а у вези с тим и на нивоу фонолошке структуре морфеме (морфофонологија)" (Пипер, Клајн 2014: 51). Са формалног становишта, граматичка категорија је „систем од најмање два члана којим се изражава неки граматички однос (нпр. род, број, падеж, лице, време итд.)" (Бугарски 2003: 146). У српском, као и у другим словенским језицима, граматичке категорије могу бити парадигматске или селективне 1 (синтагматске) природе.

У појединим граматикама (Ломпар, Антић 2014: 56) истиче се да свака граматичка категорија има најмање две вредности (нпр. категорија падежа има седам вредности: номинатив, генитив, датив, акузатив, вокатив, инструментал и локатив; категорија лица три: прво, друго, треће итд.). Оне, за разлику од нормативиста, наводе да граматичке категорије могу бити: 1) морфолошке, када за сваку вредност постоји посебан облик (нпр. придев плав може бити у мушком, женском - плава и средњем роду - плаво); 2) класификационе, када се одређена вредност приписује свакој речи посебно (нпр. именица може бити само једног рода; књига је женског рода и не може имати облик мушког или средњег рода). Тако, на пример, кажемо да придеви могу имати облике мушког, женског и средњег рода, а да се именице деле на оне мушког, женског и средњег рода". Дакле, морфолошке категорије су синоним за парадигматску природу граматичких категорија, а класификационе за селективну природу граматичких категорија. У граматикама постоји преглед граматичких категорија које имају поједине променљиве врсте речи. Међутим, у разредној настави не изучавају се све ове категорије већ се, према граматичким категоријама (Ломпар, Антић 2014: 56), могу извести програмске граматичке категорије за разредну наставу, односно појмови који су прописани програмом у разредној настави, што је приказано у наредној табели.

\footnotetext{
${ }^{1}$ Опозитивна или ужа значења исте категорије изражавају се различитим граматичким облицима исте парадигме (нпр. једнина и множина као грамеме категорије броја). Уже категоријално значење својствено је свим граматичким облицима исте лексеме и испољава се на синтагматском плану - у слагању са другим речима у реченици (нпр. категорија именичког рода) (Станојчић, Поповић 1995: 51).
} 
Табела 1. Програмске граматичке категорије променљивих речи у разредној настави

\begin{tabular}{|l|c|}
\hline Врсте речи & $\begin{array}{c}\text { Програмске граматичке категорије } \\
\text { које се усвајају у разредној настави }\end{array}$ \\
\hline Именице & род, број \\
\hline Придеви & род, број \\
\hline Заменице & род, број, лице \\
\hline Бројеви & род, број \\
\hline Глаголи & лице, број, глаголски облик, потврдност/одричност \\
\hline
\end{tabular}

У разредној настави се приликом обраде и утврђивања предвиђених променљивих речи усвајају само њихова поједина морфолошка својства. Примера ради, ученици уочавају и усвајају различите облике именских речи, иако не уче појам и функцију падежа. С обзиром на то да је род класификациона категорија, једино морфолошко обележје именица као променљиве врсте речи (које деца усвајају на нивоу разредне наставе) јесте број. Код придева се у млађим разредима основне школе изучавају род и број, а занемарени су, осим падежа, вид и степен поређења (који се усвајају само интуитивним путем). Код заменица се обрађују само род, број и лице. Када је реч о бројевима, у разредној настави се не изучавају њихова морфолошка својства, али се наглашава да су неки бројеви променљиви, а неки не. Код (личних) глаголских облика изучавају се лище, време, потврдност/одричност и граматички број, док су изузети глаголски вид, граматички род, глаголски род, стање и начин.

Да бисмо боље схватили на који начин ученици усвајају граматичке категорије променљивих речи, потребно је показати оквире досадашњих истраживања из ове области. Н. Шарановић Божовић и С. Милановић Наход (1997: 193-198) истражујући ниво усвојености и разумевања основних појмова и садржаја програмског градива у настави матерњег језика за пети разред основне школе дошле су до сазнања да ученици нису научени да откривају везе између значења и форми у језику. У овом истраживању откривено је да већина ученика не зна да промени облик групе речи, тј. синтагме или конструкције (преко 70\%). То значи да ученици нису схватили да су речи, унутар сваке групе, обједињене и повезане неким општим, граматичким значењима, односима и њиховим формалним показатељима.

М. Маринковић и Ј. Маринковић (2012: 93-101) истичу да ученици у настави граматике често погрешно тумаче значења појединих придева (најчешће су то градивни придеви), што за последицу има погрешну употребу тих придева и доносе мноштво примера који су везани за усвајање морфолошког система код деце. Ученици млађих узраста основне школе, који усвајају језичке појаве у на- 
стави граматике, најчешће у компарацији придева посебно збуњује суплетивизам. Размишљајући логички, деца теже да формирају системске облике компаратива и суперлатива и код придева који имају суплетивну компарацију. Према аналогији компарације прилога (адверба) за начин, деца често умеју да направе грешку у ситуацијама када компарирају непроменљиве прилоге.

Љ. Петровачки (2004) примећује да се у пракси често среће проблем неразликовања врсте и службе речи у реченици (нпр. када се од ученика тражи да у некој реченици одреде реченичне чланове, они одређују врсту речи, јер нису јасно разграничили морфолошки и синтаксички ниво као класе појмова).

Проблемима наставе граматике у четвртом разреду основне школе посебно се бавила Р. Драгићевић (2012). Показало се да су ученици од свих граматичких проблема који се обрађују у четвртом разреду најбоље савладали род и број заједничких и апстрактних именица. Типичне грешке јавиле су се при одређивању рода именица у множини. Закључује се да је „важно нагласити ученицима да се род именице у множини одређује и преко њеног облика у једнини, као и да се род одређује истовремено помоћу наставка и помоћу облика конгруентне речи" (Драгићевић 2012: 125).

Овом темом бавла се и В. Мићић (2016) која је у својим истраживањима дошла до закључака да један број ученика четвртог разреда основне школе (око $15 \%$ ) поистовећује придев као врсту речи са његовом атрибутском службом у реченици, али и да више од две трећине ученика препознаје атрибут, исказан придевом, у издвојеној именичкој синтагми.

\section{Методолошки оквир истраживања}

Предмет истраживања овога рада јесу мишљења учитеља о проблемима који се јављају при усвајању граматичких категорија у настави граматике на млађем основношколском узрасту. Основни проблем истраживања може се изразити у виду следећег питања: Које граматичко-морфолошке категорије речи ученици млађег узраста лакше, а које теже усвајају у настави граматике? Са циљем да детаљније испитамо мишљења учитеља о овој теми, спровели смо експлоративно истраживање. За прикупљање резултата истраживања коришћена је метода анкетирања, а за њихов опис и анализу дескриптивна метода. Узорак истраживања је намерни - анкету анонимног типа попунило је 106 учитеља који изводе наставу од првог до четвртог разреда у основним школама у Репубици Србији.

Анкетни упитник је садржао 3 питања. Укупно је четири основних хипотеза од којих смо у истраживању пошли након одређивања циља.

X1: Учитељи сматрају да је ниво усвојености правилних облика речи код ученика на крају првог циклуса основношколског образовања добар.

X2: Учитељи сматрају да већина ученика четвртог разреда основне школе разликује морфолошке од синтаксичких облика речи. 
X3: Према мишљењу учитеља, ученици најлакше усвајају род именске речи, а најтеже степен поређења придева и неких прилога.

X4: Ученицима, према мишљењу учитеља, највећи проблем при усвајању граматичких категорија представљају речи страног порекла, сложени глаголски облици и изузеци променљивих врста речи.

\section{Резултати истраживања}

Учитељи, као реализатори наставног процеса, могу да процене ниво усвојености правилних облика речи код ученика на крају првог циклуса основног образовања. Тако су дали своја мишљења о нивоу усвојености правилних облика речи код ученика на крају првог циклуса основног образовања, а резултати су приказани у следећој табели.

Табела 2. Ниво усвојености правилних облика речи код ученика на крају првог циклуса основног образовања, према мишљењу учитеља

\begin{tabular}{|c|c|c|c|c|c|c|}
\hline \multirow{2}{*}{\multicolumn{2}{|c|}{ Испитаници }} & \multicolumn{4}{|c|}{$\begin{array}{c}\text { Познавање садржаја из морфологије } \\
\text { код ученика } \\
\text { четвртог разреда јесте: }\end{array}$} & \multirow[t]{2}{*}{ Укупно } \\
\hline & & $\begin{array}{l}\text { Веома } \\
\text { добро }\end{array}$ & Добро & Довољно & $\begin{array}{c}\text { Недовољ- } \\
\text { но }\end{array}$ & \\
\hline \multirow[b]{2}{*}{ Учитељи } & $\mathrm{f}$ & 15 & 73 & 14 & 4 & 106 \\
\hline & $\%$ & $14,2 \%$ & $68,9 \%$ & $13,2 \%$ & $3,8 \%$ & $100,0 \%$ \\
\hline
\end{tabular}

Већина испитаника $(68,9 \%)$ сматра да је ниво усвојености правилних облика речи код ученика на крају првог циклуса основног образовања добар. Резултати добијени на основу првог питања потврђују нашу прву хипотезу.

Учитељи су затим исказали мишљења о томе да ли ученици на крају четвртог разреда основне школе разликују врсту речи од њихове службе у реченици, односно да ли ученици на крају четвртог разреда разликују морфолошке од синтаксичких облика речи (нпр. да ли мешају именицу и субјекат), а резултате истраживања можемо видети у следећем графикону. 
Графикон 1. Мишљења учитеља да ли ученици разликују врсте речи од службе у реченици

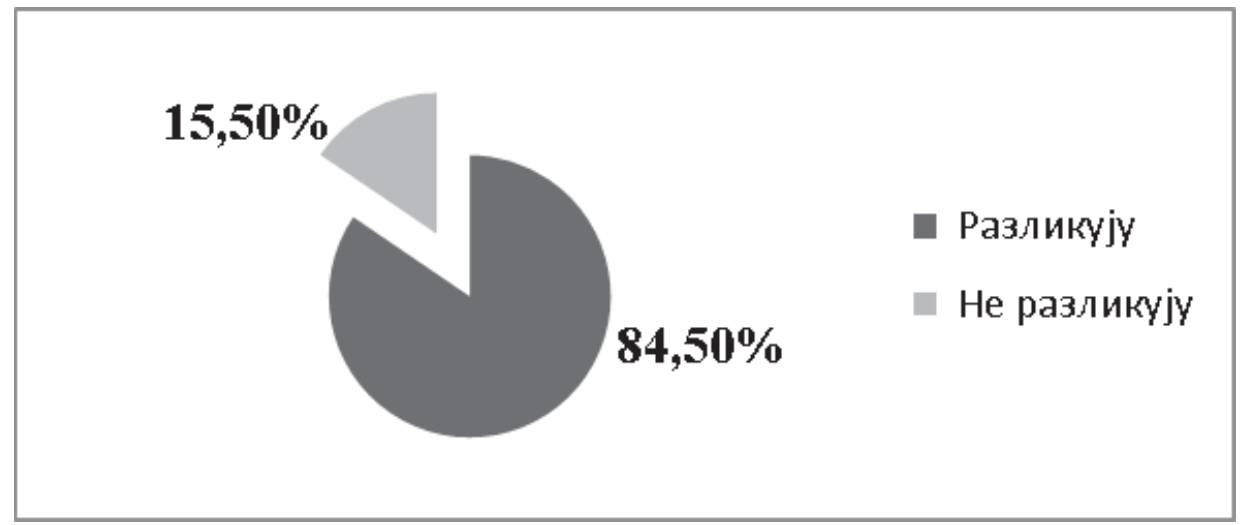

Резултати нашег истраживања показују да 84,5\% испитаних учитеља сматра да ученици разликују врсту речи од њихове службе у реченици, док $15,5 \%$ испитаних учитеља сматра да мањи број ученика није у стању да их разликује. Тих $15,5 \%$ учитеља уочило је потешкоће које се односе на разликовање следећих појмова:

a) атрибут од придева $(6,7 \%)$;

б) предикат од глагола $(3,9 \%)$;

в) прилошке одредбе за начин од придева (2,9\%);

г) субјекат од именице $(2,0 \%)$.

Њихова запажања потврђују да у пракси један број ученика (око 15\%) и даље меша морфолошке и синтаксичке појмове. Имајући у виду ове резултате, увидели смо да је друга хипотеза потврђена, али сматрамо да је задатак учитеља да на часовима српскога језика инсистира на отклањању тих грешака указујући на разлике. Упоређујући са ранијим истраживањима дошли смо до резултата који говоре да више од 15\% ученика четвртог разреда основне школе поистовећује придев као врсту речи са његовом атрибутском службом у реченици (Мићић 2016: 179). Такође, потврдили смо и да се појављује проблем неразликовања врсте и службе речи у реченици (Петровачки 2004: 61), како показују и резултати нашег истраживања.

У наредном питању анкетног упитника учитељи су методом рангирања процењивали коју граматичко-морфолошку категорију ученици најлакше, а коју најтеже усвајају интуитивним путем. Резултати су приказани у табели која следи. 
Табела 3. Мишљења учитеља о граматичким категоријама које ученици млађих разреда најлакше (1) и најтеже (7) усвајају

\begin{tabular}{|c|l|c|c|}
\hline Ранг & \multicolumn{1}{|c|}{ Граматичка категорија речи } & f & $\begin{array}{c}\text { Просечни } \\
\text { ранг }\end{array}$ \\
\hline 1. & Род именске речи & 106 & 2,01 \\
\hline 2. & Број именске речи & 106 & 2,39 \\
\hline 3. & Потврдни и одрични облик глагола & 106 & 2,98 \\
\hline 4. & Време вршења радње глагола & 106 & 3,62 \\
\hline 5. & Лице и број глагола & 106 & 4,45 \\
\hline 6. & Степен поређења придева и неких прилога & 106 & 6,19 \\
\hline 7. & Падеж именске речи & 106 & 6,37 \\
\hline
\end{tabular}

Учитељи сматрају да је род именске речи граматичка категорија коју ученици млађих разреда најлакше усвоје, што је и потврдило део наше треће хипотезе, док су граматичку категорију падежа именске речи означили као најтежу за усвајање интуитивним путем. То значи да резултати овог дела истраживања нису у потпуности потврдили трећу хипотезу.

Учитељи су, у отвореном ајтему, добили могућност да дефинишу шта ученицима млађег узраста представља највећи проблем при усвајању одређених граматичких категорија. Најфреквентији проблеми који се, према процени учитеља, јављају при усвајању рода именске речи у млађим разредима основне школе јесу: (1) мање познате речи које ученици не умеју да класификују по роду; (2) речи женског рода које се завршавају на сугласник; (3) разликовање рода именице у множини; (4) разликовање рода именске речи у контексту; (5) мешање појмова - значење, род и број именске речи; (6) мешање појмова - средњи и женски род; (7) препознавање и употреба средњег рода код неживих бића (предмета). Упоређујући са другим истраживањима, јавиле су се сличне, типичне грешке (Драгићевић 2012; Ломпар, Антић: 2014). Учитељи (95,3\%) су навели да ученици најчешће мешају множину именица и збирне именице (које обликом једнине значе множину) при усвајању броја именске речи, а да их збуњује граматичка категорија броја збирних именица. Према мишљењу учитеља, највећи проблем код ученика јесте неправилно писање одричне речце не са глаголима у личном облику. Ученици имају потешкоћа при одређивању сложених облика глагола у тексту, а мешају и потврдне и одричне облике глагола. То нам говори да су потребни интензивнији часови утврђивања и обнављања градива, односно повезивање часова граматике са наставом правописа.

Ученици млађег школског узраста у периоду усвајања времена вршења радње глагола, према речима учитеља, поистовећују садашње и будуће време, 
те мешају појмове - футур, презент и перфекат. Дакле, мање имају проблема са препознавањем и употребом глаголског облика у прошлом времену. Највећи проблем ученицима представља облик глагола у будућем времену. Ако упоредимо резултате овог истраживања са резултатима истраживања до којих је дошла Р. Драгићевић (2012), можемо закључити да су они веома слични.

При усвајању лица и броја глагола, учитељи су навели да ученици тешко усвајају треће лице множине, мешају лице и број глагола, те да је потребно издвојити више времена за утврђивање ове граматичке категорије. Код поређења придева и неких прилога наведени су следећи проблеми у настави: (1) ученици теже пореде придев у контексту (реченици); (2) мешају придеве и прилоге; (3) одвојено пишу префикс нај- са компаративом код облика у суперлативу; (4) ученике збуњују изузеци - придеви са неправилним поређењем; (5) неправилно изговарају и пишу неке облике придева и прилога у компаративу и суперлативу (нпр. мастан - машћи - најмашћији, уместо маснији и најмаснији). Правилно усвајање падежа именске речи, према речима учитеља, отежавају следећи фактори: (1) утицај дијалекатске околине ученика и говора родитеља и (2) контекст у коме се користе облици речи чији падеж треба одредити.

\section{Закључна разматрања}

Поставља се питање како помоћи ученицима да лакше и логичније усвоје граматичке категорије речи, како би убудуће само надограђивали своја знања у настави, али и ван ње. Треба се ослонити на теоријска мишљења психолога, педагога, психолингвиста и лингвиста, али и на методичка решења самих методичара и учитеља. Стога бисмо укратко предложили следећа методичка решења за превазилажење проблема у настави граматике при усвајању граматичких категорија: а) ученицима треба понудити садржаје који ће бити прилагођени њиховим могућностима - парадигматске књижевне текстове и језичке игре; б) захтеве ученицима прилагодити њиховом узрасту - постављати концизна питања и давати конкретне и типичне примере за усвајање, вежбање, обнављање и проверу градива; в) омогућити ученицима да сами откривају садржај и значење језичке појаве уз прецизно и стручно вођење учитеља; г) примењивати одговарајуће методе (сазнајне путеве), принципе и поступке рада, речју, поштовати методичке захтеве прилагођене ученицима млађег узраста; д) олакшати усвајање научних појмова коришћењем разноврсних савремених техничких средстава; ђ) прилагођавати и моделовати методичку структуру часа наставе граматике; е) ставити акценат на контекст и језички систем - језичке појаве не треба изучавати ван добро одабраних или осмишљених (квалитетних) лингвометодичких текстова и ж) упоређивати правилне облике речи са погрешним облицима које употребљавају најчешће деца из социјално угрожених породица и руралних средина, речју, треба што више указивати на разлику између књижевног и дијалекатског говора. Зато је веома важно да сви учитељи са ученицима увежбавају и обнављају гра- 
матику, као и да прате савремене токове истраживања и тиме непрестано надограђују своје знање и способности.

\section{ЛИТЕРАТУРА}

Бугарски 2003: Р. Бугарски, Увод у општу лингвистику, Београд: Чигоја штампа.

Виготски ${ }^{2}$ 1996: Л. Сергејевич Виготски, Проблеми опште психологије, Београд: Завод за уџбенике и наставна средства.

Вилотијевић 2000: М. Вилотијевић, Дидактика 2: Дидактичке теорије и теорије учеља, Београд: Научна књига; Учитељски факултет.

Драгићевић 2012: Р. Драгићевић, Лексикологија и граматика у школи: методички огледи, Београд: Учитељски факултет.

Лазаревић 1999: Д. Лазаревић, Од спонтаних ка научним појмовима - развој научних појмова кроз наставу и школско учење, Београд: Завод за уџбенике и наставна средства.

Ломпар и Антић 2014: В. Ломпар, А. Антић, Граматика: српски језик и кьижевност: за други разред гимназија и средњих стручних школа, Београд: Klett.

Маринковић и Маринковић 2012: М. Маринковић, Ј. Маринковић, „Творба речи и усвајање морфолошког система код деце", Свет речи: часопис за сpnски језик и книжевност, 2, Београд, 93-101.

Мићић 2016: В. Мићић, Синтакса просте реченице у разредној настави, Београд: Учитељски факултет.

Милатовић 2011: В. Милатовић, Методика наставе српског језика и књижевности у разредној настави, прир. 3. Цветановић, В. Јанићијевић, В. Мићић, Београд: Учитељски факултет.

Оусубел 1962: D. P. Ausubel, A Subsumption Theory of Meaningful Verbal Learning and Retention, Journal of General Psychology, LXVI/2, 213-224.

Петровачки 2004: Љ. Петровачки, Синтакса у настави српског језика и кьижевности, Нови Сад: Змај.

Пијаже, Инхелдер 1982: Ž. Pijaže i B. Inhelder (J. Piaget, B. Inhelder), Intelektualni razvoj deteta: izabrani radovi, Beograd: Zavod za udžbenike i nastavna sredstva.

Пипер, Клајн 2014: П. Пипер, И. Клајн, Нормативна граматика српског језика, друго измењено и допуњено издање, Нови Сад: Матица српска.

Правилник о наставном плану и програму за први и други разред основног образовања и васпитања 2004: Правилник о наставном плану и програму за први и други разред основног образовања и васпитања, Београд: Службени гласник РС-Просветни гласник, бр. 10, Београд, 2-10. 
Правилник о наставном програму за трећи разред основног образовања и васпитања 2005: Правилник о наставном програму за трећи разред основног образовања и васпитања, Београд: Службени гласник РС - Просветни гласник, бр. 1, Београд, 2-9.

Правилник о наставном програму за четврти разред основног образовања и васпитања - Српски језик 2006: Правилник о наставном програму за четврти разред основног образовања и васпитања, Београд: Службени гласник $Р C$-Просветни гласник, бр. 3, Београд, 4-11.

Станојчић и Поповић 1995: Ж. Станојчић и Љ. Поповић, Граматика срискога језика - уцбеник за I, II, III и IV разред средюе школе, Београд: Завод за уџбенике и наставна средства.

Цветковић 1982: Ж. Цветковић, Усвајаъе појмова у настави, Београд: Завод за уџбенике и наставна средства.

Шарановић Божовић и Милановић Наход 1997: Н. Шарановић Божовић и С. Милановић Наход, „Усвајање појмова у настави матерњег језика”, Београд: Зборник института за педагошка истраживања, XXIX/29, 189-199.

Ljiljana J. Kelemen Milojević Zorica V. Cvetanović

TEACHERS' ATTITUDES TOWARDS ACQUIRING OF GRAMMATICAL CATEGORIES IN THE SERBIAN LANGUAGE CLASSES IN PRIMARY SCHOOL

Summary

The acquisition of morphological elements, especially certain grammatical categories, is a curriculum task in primary schools. The goal of the paper is to present grammatical categories of words which are defined and learned in primary schools, to put forward a study on the acquisition of the aforementioned elements and possible solutions for overcoming the noted problems in the grammar classes. The teaching program, which is proposed by the Ministry of Education of the Republic of Serbia, presupposes a gradual and systematic teaching of morphology content. In the first grade only the concept of the word is introduced in the aforementioned area. The pupils gradually notice basic grammatical categories, firstly words which change their forms and meanings depending of the word function, and only in the fourth grade of elementary school are pupils introduced to function words without noting the parts of speech. 
In the primary school period not all grammatical categories are taught, but only the ones which are proposed in the teaching program, i.e. content words with certain grammatical categories. Studies in the area of grammar teaching include morphology content. Certain problems were noticed which refer to the typical mistakes of pupils and the ways in which they can be overcome, with the accent on the methodological approach in class.

In this paper we give the results of a study conducted with a goal to explore the opinions of teachers about the problems which occur during the learning of grammatical categories by younger learners. An anonymous questionnaire was filled out by 106 teachers in 11 primary schools on the territory of the Republic of Serbia. The results show that learners experience the most difficulty with less familiar words of the Serbian language and exceptions in the noun changes; most young learners do not differentiate grammatical-morphological concepts, they write the negative grammatical particle no with verbs in the personal form and they incorrectly write and pronounce some forms of adjectives and adverbs in the comparative and superlative. This tells us that more intensive, methodically modelled classes of practice and consolidation are needed, i.e. connecting grammar classes with literature, culture and orthography classes.

Keywords: grammatical categories, morphology, function words, grammar teaching, Serbian language classes. 